\title{
RELATIONSHIP BETWEEN PARENTAL INVOLVEMENT \& ACADEMIC ACHIEVEMENT: A CASE FOR SECONDARY SCHOOL STUDENTS IN SOUTHERN PUNJAB, PAKISTAN
}

\author{
Muhammad Athar Hussain \\ Associate Professor \\ Department of Education, The Islamia University of Bahawalpur, \\ Punjab, Pakistan \\ Email: athar.hussain@iub.edu.pk

\section{Imtiaz Ahmad} \\ Assistant Professor, \\ Department of Techer Education, University of Karachi, \\ Sindh, Pakistan \\ Email: imtiazjam@uok.edu.pk \\ Ann Samson \\ Assistant Professor (IPFP), \\ Department of Education, FUUAST, Karachi, \\ Sindh, Pakistan \\ Email: dr.annsamson@ fuuast.edu.pk
}

\begin{abstract}
The study aims to investigate the impact of involvement by the parents on children's academic performance. Teachers and parents were requested to respond about effectiveness of activities under different categories of parental involvement i.e. collaborating with community, decision making, learning at home, volunteering, communicating and parenting. The sample of 100 adult students was selected from high schools of District Rahim Yar Khan, Pakistan, to investigate the relationship between parental involvement and students' academic performance. Parental involvement scale, comprised of 30 items was administered on parents to access their involvement level while academic performance scale, comprised of 19 items was administered on students to access their academic performance. Descriptive statistics and student's t-test were used to analyze the collected data and findings of analysis revealed that there is significant positive relationship between parental involvement and academic performance of students i.e. students have better academic performance if their parents have more involvement.
\end{abstract}


KEYWORDS

Parental Involvement, Academic Achievements, Secondary Schools

\section{INTRODUCTION}

Different studies have identified that the parental involvement in lives of children have significant impact on success of their lives specifically in their academic performance. The parental involvement is of different types, varied significantly among different cultures and societies. Similarly, the parental involvement has contribution in attitude and behavioral aspects of children, their level of motivation, goals and objectives, selfconcept and so forth. Studies have identified significant positive impact of parental involvement on these behavioral and attitudinal outcomes.

Parental involvement is the participation from parents in all the aspects of development and education, from birth to adulthood, recognizing that parents are of primary influence in lives of children. Wartman and Savage, (2008) mentioned the involvement by the parents as "interest of parents in lives of children throughout their lives, providing guidelines and encouragement to the students and then retaining the institutional connection beyond college years.

One of the most important frameworks which deal with the parental involvement of different types and its impact on different outcomes is the Epstein's Model of Parental Involvement. Types of parental involvement include parenting (parenting skills and facilitating the children and families), Communication (ability of developing efficient and effective home-school communication), volunteering, decision making, learning at home, and collaboration with the community (Epstein, 1995).

In general, parents are usually not directly involved in students' learning and teaching activities as the educational institutions. Parents are indirectly involvement in learning and teaching activities for instance by providing their children with financial and other resources, developing an educational culture or environment within their homes, and other supports for their schooling. The interaction of parents with their children is significantly influenced by the cultural and socio-economic factors like the way a family is managing the learning activities of their children is strictly depending upon socio-economic condition of family and resources they have in term of money and time. According to Fan, (2001), the parental involvement and support is the multidimensional construct.

\section{LITERATURE REVIEW}

Different empirical studies have identified different types of parental involvement, having different influences on achievement of adolescents and children. Similarly, different studies have investigated the impact of parental involvement on children's 
academic achievements and identified that the parental involvement has significant impact on learning of children. For instance, Okapala et. al., (2001) identified that economic conditions and facilities provided by the parents to their children have significant impact on academic achievement of students. Similarly, studies like Gonzalez, et. al., (2002); Mahaffy, (2004) and Franco and Levitt, (1998) identified that the involvement of parents in academic activities of their children is significantly influencing the academic achievement of high school students.

Rc Martin (1995) identified that the student's failure in school is playing significantly important role in creating negative self-image. The interaction of parents and their children is strongly influenced by the cultural and socio-economic factors in particular society. Similarly, the learning activities are significantly influenced by the socioeconomic position as well as financial position and resources in term of time and money.

Fan et. al., (2001) identified that the parent's expectations with children regarding their academic achievements significantly influence their actual performance at school. The study also identified that impact of supervision by teachers on academic performance of students is marginal. Desforges and Abouchaar, (2003) identified different involvement initiatives by parents as 'good' parenting i.e. provision of stable and secure environment, discussion between parents and children, intellectual stimulation, high level aspirations regarding personal fulfillment, role model for educational and constructive social values, participation and involvement in homework, good citizenship contact with the educational institution aimed to share information about participation in school events, and the participation by parents in governance of school.

Motivation, as an internal force or phenomenon is strongly affected and influenced by different dimensions of context (external stimuli and environment), goals (regarding inclination, purpose, and behavior), temper (i.e. the internal aspects of individual), and the instruments (i.e. different instruments used to achieve goals and objectives). Individuals are acquiring sufficient amount of motivation in order to achieve their goals and objectives, fulfilling their needs and wants and other related aspects. Specifically, in case of students, motivation to achieve good academic performance is very critical and important.

The motivation is stimulating individuals to complete their assignments successfully, achieving goals and objectives, higher qualification in respective fields. Motivation, specifically in educational perspective is comprised of different dimensions and aspects, related specifically with the learning and academia related motivation. Mohammadi, (2006) categorized the academic motivation into two broad categories internal and external, and mentioned that the external motivation influence the 
individual with independent goals that undertake the specific activities. Internal motivation, on the other hand is providing the sufficient incentive to perform particular task.

Noble and Farah, (2006) conducted study to identify the factors having influence on academic performance of high school students and identified that the proper guidance from parents has significant impact on performance of students. Other factors identified by the study include positive attitude, perception of students to cope up with difficulties, coping strategies, different background aspects and characteristics like education level of parents, their family income, number of negative situations at home, guidance from parents and so forth, having significant but indirect impact on composite score of individuals.

Students have to face and resolve different issues in order to develop positive study habits and attitudes. Students can improve their study habits and attitude through parental guidance, which is directly proportional to the academic achievement of students. Similarly, Hussain (2003) identified that the students having proper guidance from parents have high performance in exams, also having significant impact on performance of students.

Parental involvement, by the researchers is considered as significant force, contributing in academic achievement of students. Epstein et. al., (2009) identified that the communities, schools and parents have shared responsibilities and interest in educating children. SFC (School, Family and Community) model focused on roles of family, school and community on learning and development of children. Researcher mentioned that this partnership model has significant but overlapping influence on children and their efforts of achieving academic success.

Another important theory of overlapping sphere of influence focused on relationship between educators, family, community and children's academic achievement and mentioned that educators are providing family like environment in schools and families are providing school like homers while communities are encouraging family like services and school like opportunities to children, having significant impact of children's academic performance. The description of model include that educators and schools are offering home like or family like environment, recognizing the children as individuals while making them feeling valuable. Parents, similarly are creating school like environment at homes and for this they recognize the different activities usually performed in schools only, facilitating the children to have better success in their academia. Communities, finally, are offering the children with opportunities offered in schools and events and other facilities that encourage the families to support the children in having success in academia. 
Based on studies identified above, it is identified that extensive research has been conducted on parental involvement and success of students in their academia and almost all the studies identified above have found significant positive correlation between parental involvement in children and their academic success. During literature survey it is identified that this relationship is not tested and investigated in context of Pakistan specifically among students of Sothern Punjab Region, motivated to conduct this study.

\section{RESEARCH OBJECTIVES}

1. To identify the level of parental interest and involvement among families in District Rahim Yar Khan.

2. To investigate the role of parental support in academic success of students in District Rahim Yar Khan.

3. To identify the current academic achievements and success among students in District Rahim Yar Khan.

4. To investigate the relationship between parental involvement and academic success of students in District Rahim Yar Khan.

5. To identify the relationship between factors influencing relationship between parental involvement and students' success in academia among students in District Rahim Yar Khan.

\section{RESEARCH HYPOTHESES}

Following hypotheses are developed and investigated during course of this study.

1. There is significant positive relationship between parental involvement and students' academic achievements.

2. Male and female students are significantly different with respect to the relationship between parental involvement and success in academia.

3. $9^{\text {th }}$ and $10^{\text {th }}$ grade students are significantly different with respect to the relationship between involvement of parents and academic success.

\section{RESEARCH METHODOLOGY}

The subject study is aimed to identify and investigate relationship between involvement by the parents and the academic performance of children. In order to achieve this aim, sample of 100 students (50 male and 50 female) from high schools of district Rahim Yar Khan was selected at random. Data was collected through structured questionnaire, prepared after reviewing relevant literature. Two different scales were used firstly, the parental involvement scale, comprised of 30 items, aimed to identify the current parental involvement level in selected students' school related activities. Secondly, the students' academic performance scale, comprised of 19 items was used to identify the academic performance of selected students. Collected data 
was analyzed by using descriptive statistics, ANOVA, t-test and Pearson's correlation coefficient, by using SPSS (Statistical Package for Social Sciences).

\section{RESEARCH FINDINGS}

Table 1

Frequency Table with respect to Gender and Grade:

\begin{tabular}{lccc}
\hline Respondent's Characteristics & Frequency & Percentage \\
\hline Gender & Male & 50 & 50 \\
& Female & 50 & 50
\end{tabular}

Education

$\begin{array}{lll}9^{\text {th }} \text { Class } & 50 & 50 \\ 10^{\text {th }} \text { Class } & 50 & 50\end{array}$

The above table is showing the frequencies of male and female students as well as their grades. The table has shown that among 100 selected students, 50 were male students while 50 were female students. Similarly, 50 per cent of selected students were form $9^{\text {th }}$ grade while remaining 50 per cent were from $10^{\text {th }}$ grade, summarized in figure 1 below.

\section{Proporation of Male and Female Students in Sample}

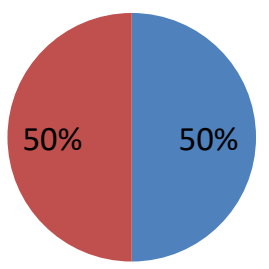

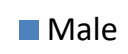

Female

\section{Prportion of Students with respect Academic Grades}

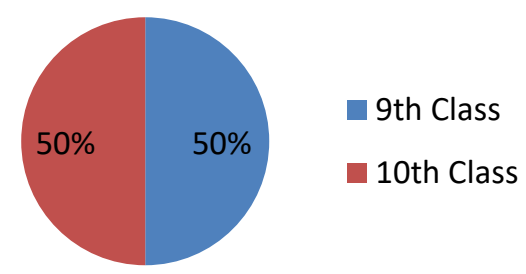

Figure 1: Proportion of Male and Female Students and $9^{\text {th }}$ and $10^{\text {th }}$ Grade Students

Table 2

Descriptive Statistics and Independent t-test for Gender Differences

\begin{tabular}{|c|c|c|c|c|c|c|c|}
\hline \multirow[t]{2}{*}{ Variables } & \multicolumn{2}{|c|}{ Male $(\mathrm{N}=50)$} & \multicolumn{2}{|c|}{ Female $(\mathrm{N}=50)$} & \multirow[b]{2}{*}{$\mathrm{T}$} & \multirow[b]{2}{*}{ Df } & \multirow[b]{2}{*}{$\mathrm{P}$} \\
\hline & $\mathrm{M}$ & SD & $\mathrm{M}$ & SD & & & \\
\hline $\begin{array}{l}\text { Parental } \\
\text { Involvement }\end{array}$ & 50.70 & 11.20 & 43.80 & 9.39 & 3.34 & 98 & .001 \\
\hline
\end{tabular}




\begin{tabular}{llllllll}
\hline $\begin{array}{l}\text { Academic } \\
\text { Achievement }\end{array}$ & 40.88 & 6.23 & 36.20 & 5.21 & 4.07 & 98 & .000
\end{tabular}

The table above is showing the results of descriptive statistics and student's t-test for gender differences with respect to the relationship between parental involvement and academic achievement of students. Parental involvement mean among males is high as compared with the female respondents. Similarly, the t-value is 3.34, which is significant at $\mathrm{p}=0.001$. Additionally, the mean of males with respect to academic achievement is also high if compared with the female respondents. T-value is 4.07, which is significant at $\mathrm{p}=0.000$.

Table 3

Descriptive Statistics and Independent t-test for Grade (Class) Differences

\begin{tabular}{lccccccc}
\hline \multicolumn{1}{c}{ Variables } & $\mathbf{9}^{\text {th }}$ class $(\mathbf{N = 5 0}$ & \multicolumn{6}{c}{$\mathbf{1 0}^{\text {th }}$ Class $(\mathbf{N = 5 0})$} \\
\hline Parental & M & SD & M & SD & T & Df & P \\
$\begin{array}{l}\text { Involvement } \\
\begin{array}{l}\text { Academic } \\
\text { Achievement }\end{array}\end{array}$ & 48.12 & 11.18 & 46.38 & 10.56 & .80 & 98 & .426 \\
\hline
\end{tabular}

The table above is showing the comparison between $10^{\text {th }}$ grade and $9^{\text {th }}$ grade students and identified if there is significant difference between $9^{\text {th }}$ and $10^{\text {th }}$ class students with respect to the relationship between parental involvement and academic achievements. Mean score of parental involvement scale for $9^{\text {th }}$ class students is high as compared with the students of $10^{\text {th }}$ class. Similarly, t-value is 0.80 while significant value is 0.426 . The mean score of academic achievement scale for $9^{\text {th }}$ class students is also significantly high from mean score of $10^{\text {th }}$ class students. T-value for $9^{\text {th }}$ class students is 3.11 while the significance value is 0.002 .

Table 4

Bivariate Correlations among School Students with Parental Involvement and Academic Achievement

\begin{tabular}{ll} 
& Academic Achievement \\
\hline Parental Involvement & 1 \\
Academic Achievement & $.21^{*}$ \\
\hline$* *$. Correlation is significant at the 0.05 level (2-tailed).
\end{tabular}

The table above is showing the bivariate correlation coefficient among selected students with respect to their parental involvement and level of academic achievement. The results have shown that there is significant positive correlation between academic achievement of students and involvement level of their parents. 


\section{CONCLUSION AND DISCUSSION}

The study is aimed at identifying the relationship between parental involvement and academic performance and achievement of high school students in district Rahim Yar Khan. The findings of student revealed that the involvement by the families and parents is strongly positively correlated with the success of students in their academia. The development sequence is identified i.e. earlier support from family enable the students to develop better academic status as well as the positive self-concept, contributing to the maturation of students' career and personality.

The study also has identified that the parental involvement and support in different academic activities specifically in doing homework, has significant influence on the academia related performance and achievement of students. These findings are consistent with Eilam, (2001) and Singh et. al., (2002). Study also has supported the findings of Mahaffy, (2004) i.e. parental involvement has significant impact on students' self-concept.

Findings of study also included that about 50 per cent students are receiving private tuitions after school. Similarly, more than $40 \%$ students have mentioned that they have no support of any type from their parents. This shows the belief of parents that only schools are responsible for teaching related aspects of their children and they do not have any responsibility over this. In addition, most of the parents due to the financial constraints were found with no time to spend on children and other family matters. Another reason, as identified was that most of the parents were illiterate, therefore were unable to provide proper training and coaching at home to the children.

The review of relevant literature identified that the parents' socioeconomic status and students' age are important factors, contributing in extent of support that the parents provided to their children (Chohan and Khan, 2010). Gestwicki (1996) identified that parents' support during early years is of utmost importance for learning patterns of children.

Henderson et. al., (1981, 1987 and 1995) mentioned that the importance of parenting for children and their academia cannot be over emphasized. In addition, the findings of this study are consistent with the findings of Gestwicki, (1996), mentioned that parental involvement has significant positive impact on educational achievements, cognitive growth, and learning styles. This study, although did not investigated the parenting styles, which would be interesting for future investigation. Velez and Jones (1997) mentioned that parents of students with high grades and success are using intrusive parenting style. This information would be useful specifically for development of parent involvement programs and parenting classes. 
This study also has identified that about $71 \%$ respondents are either frequently or always contacting their teachers specifically if their children have any problem or issue. The study also identified the range of total score for respondents and found it 40 i.e. there is 40 point variation in total score of respondents. In addition the correlation coefficient between behavior score for parent involvement and children's achievements is 0.61 , showing significant positive correlation and significant at $5 \%$ level of significance. This shows that the parental involvement has significant positive correlation with the success of children.

\section{RECOMMENDATIONS}

Subject study was structured and organized to determine how parental involvement influence the grades and performance of children in their academia and academia related activities. The study was also aimed to identify if there is any significant difference between male and female students and $9^{\text {th }}$ and $10^{\text {th }}$ grade students, with respect to involvement of parents and academic success of children. The data was collected through two different scales, parental involvement scale and students' achievements scale, and analyzed through t-test, descriptive statistics and correlation coefficient.

It was identified that involvement by the parents in studies and study related activities is correlated significantly with success of students in their academia. Parents' involvement in study related activities of their children has significant impact on academia related performance of children. Additionally, study has identified that the relationship between parental involvement and academic achievements is strong among male children as compared with female. In addition, this relationship between constructs is found stronger among students of $9^{\text {th }}$ class as compared with students of $10^{\text {th }}$ class. The research has attempted to determine relationship between parental involvement and academic achievement of students with special reference to Southern Punjab region. Thus, the research informs designing a comprehensive plan for Parental Involvement, School Community \& Teacher relationship and responsibility of School Administration towards Parenting Education in order to materialize and sustain students' academic achievement through the interplay of multiple factors.

\section{REFERENCES}

Chohan,I.B., Khan, M.R.(2010). Impact of Parental Support on the Academic Performance and Self Concept of Student. Journal of Research and Reflections in Education, 4(1), 14-26.

Desforges, C. and Abouchaar, A. (2003). The impact of parental involvement, parental support and family education on pupil achievement and adjustment: $A$ literature review. Report Number 433, Department of Education and Skills. 
Eilam, B. (2001). Primary Strategies for Promoting Homework Performance, American Educational Research Journal, 38( 3), pp. 691-725.

Epstein, J. L, Sanders, M. G., Simon, B. S., Salinas, K. C, Jansorn, N. R., \& Van

Voorhis, F. L. (2009). School, family, and community partnerships: Your handbook for action. Thousand Oaks, CA: Corwin Press.

Epstein, J.L. (1995). School/family/community partnerships: Caring for the children we share. Phi Delta Kappan (May), 701-712.

Fan, X., and Chen, M. (2001). "Parental Involvement and Students' Academic Achievement: A Meta-Analysis." Educational Psychology Review 13(1):

Franco, N. \& Levitt, M.J. (1998) The Social Ecology of Middle Childhood: Family Support, Friendship Quality, and Self-Esteem. Family Relations, 47( 4),pp. 315321

Gestwicki, C. (1996). Home, school and community relations: A guide to working with parents. Albany, NY: Delmar.

Gonzalez - Pienda, J. A, Nunez, J. C., Gonzalez - Pumariega, S., Alvarez, L., Roces, C. \& Garcia, M. (2002). A Structural Equation Model of Parental Involvement, Motivational and Aptitudinal Characteristics, and Academic Achievement. The Journal of Experimental Education, 70(3),pp. 257-287.

Henderson, A. \& Berla, N. (1995). A new generation of evidence: The family is critical to student achievement. Washington DC: Center for Law and Education.

Henderson, A. 1987. The evidence continues to grow: parent involvement improves student achievement. Columbia, MD: National Committee for Citizens in Education. 1988. Parents are school's best friend. Phi Delta Kappan (October):148-153.

Henderson, R.1981. Home environment and intellectual performance. In parent-child interaction: theory, research and prospects, edited by R. Henderson. New York: Academic Press.

Hussain, M. (2003). Problems, importance and solution of education department. Talimi Zaviay, 13(3), 49-51.

Mahaffy , K. A. (2004). Girls' Low Self-Esteem: How Is It Related to Later Socioeconomic Achievements? Gender and Society, 18 (3), pp. 309-327.

Martin, R. C. (1995). Working memory doesn't work: A critique of Miyake et al.'s capacity theory of aphasic comprehension deficits. Cognitive Neuropsychology, $12,623-636$.

Mohammadi, S.H. (2006) Teachers' Burnout and Psychological Health. Journal of Iranian Psychologists, 3, 15-23.

Noble, K.G., Farah, M.J., \& McCandliss, B.M. (2006). Socioeconomic background modulates cognition-achievement relationships in reading. Cognitive Development, 21 (3), 349-368.

Okpala, C.O., Okpala, A.O, \& Smith, F.E. (2001). Parental Involvement, Instructional Expenditures, Family Socioeconomic Attributes, and Student Achievement. The Journal of Educational Research, 95( 2), pp. 110-115

Shami, P. A., \& Hussain, K. S. (2006a). Development of Education in Pakistan. Islamabad: Academy of Educational Planning and Management, Ministry of Education. 
PJER, Vol 3, Issue 2 (2020)

Relationship between parental...

Singh, K., Granville, M., and Dika, S. (2002). Mathematics and Science Achievement: Effects of Motivation, Interest, and Academic Engagement, The Journal of Educational Research, 95 (6), pp. 323-332.

Velez, William and Jones, Toni Griego, (1997, February). Effects of parent involvement on the academic achievement of Latino children. Research and Opinion, 11(1).

Wartman, K. and Savage, M. (2008). Parental involvement in higher education. ASHE Higher Education Report, 33(6), 1-125. 